\title{
PERFORMANCE, LABOUR FLEXIBILITY AND MIGRANT WORKERS IN HOTELS: AN ESTABLISHMENT AND DEPARTMENTAL LEVEL ANALYSIS
}

\author{
Natina Yaduma \\ Assistant Professor \\ Economics Discipline Area \\ American University of Nigeria \\ Allan Williams \\ Chair in Tourism and Mobility Studies \\ School of Hospitality and Tourism Management \\ University of Surrey \\ Andrew J Lockwood \\ Forte Professor of Management \\ School of Hospitality and Tourism Management \\ University of Surrey \\ Sangwon Park \\ Senior Lecturer \\ School of Hospitality and Tourism Management \\ University of Surrey
}

\section{Citation}

Yaduma, N., Williams, A., Lockwood, A. J., \& Park, S. (2015). Performance, labour flexibility and migrant workers in hotels: An establishment and departmental level analysis. International Journal of Hospitality Management, 50, 94-104. 


\title{
PERFORMANCE, LABOUR FLEXIBILITY AND MIGRANT WORKERS IN HOTELS: AN ESTABLISHMENT AND DEPARTMENTAL LEVEL ANALYSIS
}

May 2014

\begin{abstract}
This paper analyses flexible working, and the employment of migrants, as determinants of performance in hotels, utilising a highly disaggregated data set of actual hours worked and outputs, on a monthly basis, over an 8 year period for 25 establishments within a single firm. It examines not only inter-establishment, but also intra-establishment (departmental) variations in performance. The analysis also systematically compares the findings based on financial versus physical measures, against a background where existing research has utilised diverse and, sometimes, hybrid measures of performance and productivity. While generally confirming significant relationships between performance and flexible working and migrant employment, the findings also emphasise that the types of flexible working practices are important. It also identifies complex variations at the departmental level: substantially different relationships between flexibility and migrant employment, and performance are identified for rooms versus food \& beverage departments, reflecting different operating conditions.
\end{abstract}

\section{Keywords}

Labour Productivity, Physical Performance, Financial Performance, Numerical Flexibility, Functional Flexibility, Migrant Employment, Zero-contract Employment 


\section{Introduction}

There has been sustained academic and policy interest in the UK over several decades in the so-called 'productivity gap' or international differentials in productivity (e.g. Griffith et al. 2003). Researchers have acknowledged the heterogeneous nature of productivity (Bartelsman and Doms 2000), not only differentiating the service and manufacturing sectors but also focussing on individual sector and firm/establishment-level studies. This paper advances this research agenda by analysing the relationship between flexible working, and the employment of migrant workers to performance within a single hotel chain - a sector with one of the lowest productivity levels in the UK (Griffith et al. 2003).

Flexible working is a key decision variable for management. This is particularly significant in hotels, given the highly variable demand, the uno-actu feature of being unable to stockpile unsold supply (Jones and Lockwood 2002) and competitive markets. Several forms of flexible working can be utilised with the aim of enhancing performance (Lockwood and Guerrier 1989; Kelliher 1989), but with contradictory evidence as to whether these have positive or negative impacts on productivity (Michie and Sheehan 2005). Another labour market feature is increasing migrant employment in the hospitality sector in the UK and most other developed economies (Markova et al. 2013), although the contribution of migrant workers to labour productivity is contested (Huber et al. 2010) and surprisingly underresearched at the micro as opposed to the macro level (Kangasniemi et al. 2009) largely due to data constraints. There are very few studies at the establishment (hotel) level, and even fewer at the departmental (rooms versus food and beverage) level.

Building on this literature, this paper addresses the following research questions in relation to a single medium sized hotel chain with 25 establishments in the UK. First, what is the relationship between labour productivity (performance) and flexible working practices? Second, what is the relationship between performance and the employment of international 
migrants? Third, to what extent are these relationships consistent when physical versus financial measures of performance are utilised, and at the establishment versus departmental levels? While labour productivity is traditionally based on the relationship between gross output or value added and the number of hours worked, this paper analyses financial performance (the ratio of financial revenues to labour costs) and physical performance (the ratio of physical output - occupied room nights or food and beverage covers - to labour hours). Labour flexibility is the variability in the hours worked by individual employees over time or between departments.

The paper makes three main contributions. First, by drawing on privileged access to a unique data set, performance differentials are analysed at not only the establishment level within this firm, but also at departmental levels (rooms, and food \& beverage), revealing important inter and intra-establishment variance, that signals the need for highly targeted policy and practice interventions. Second, it examines differences in performance depending on whether financial or physical measures are utilised: this is important because researchers on hotel productivity have utilised an often confusing mixture of such measures, without due recognition of the implications for the subsequent analyses. Here we use the more generic term performance, to compare financial and physical performance measures that provide insights into hotel productivity. Third, it provides a detailed empirical analysis of the relationship between performance and actual hours worked flexibly and by migrants, on a monthly basis over an 8 year period.

The rest of the paper is organised as follows. The second section reviews the existing literature, the third outlines the methodology, the fourth presents the findings and discussion, and the final part summarises the major contributions and proffers future areas of research. 


\section{Literature Review}

\subsection{Productivity in the Service Sector: Partial Measures and Heterogeneity}

Although there has been some shift from measuring partial productivity, usually labour productivity, to total factor productivity (Gronroos and Ojasalo 2004), the relatively widespread separation of ownership of assets (buildings) and hotel operations blurs the relationship with capital inputs in this sector. Technological differences are relatively limited amongst - let alone within - major hospitality companies (David, Grabski, and Kasavana 1996; Rust and Huang 2012). Moreover, the labour intensive nature of the hospitality industry (Ball, Johnson, and Slattery 1986; Mill 2008; Rust and Huang 2012) reinforces the importance of labour productivity (Higon et al. 2010). Labour-related performance measures are the focus of this paper and we address gaps in the understanding of the different perspectives provided by physical and financial measures, and inter-departmental level differences.

Despite consensus about the importance of labour productivity measures in hotels, the intangible and experiential characteristics of service makes it difficult to define and measure inputs and outputs (Jones and Siag 2009), and productivity (Jones and Lockwood 2002; Witt and Witt 1989). There is intense debate about whether productivity should be measured in physical or monetary terms (Foster, Haltiwanger, and Syverson 2008). The choice of productivity measures is mostly driven by data availability. Physical measures have limitations in capturing the quality of inputs and outputs, whereas this is implicit in wages and prices. Prices, however, are influenced by market imperfections (Reynolds et al. 2005). Although physical measures have been utilised (Ball et al. 1986; Brown and Dev 2000; Hu and Cai 2004; Johns et al. 1997; Mason, Robinson, and Bondibene 2009), most research on hotels employs financial measures or composite measures combining physical and financial measures (Anderson et al. 1999; Barros 2005; Hu and Cai 2004; Sigala et al. 2005). These often do not strictly accord with the standard generic measures of productivity (OECD 2001), and there is 
a gap in terms of comparing financial and physical measures of hotel productivity, even though these provide mutually-informing perspectives (Foster et al. 2008); a point we return to in the methodology.

A second significant gap in the literature on hotel productivity relates to heterogeneity. This is a recurring theme in the general literature on productivity (Bloom and van Reenen 2010; Faggio, Salvanes, and van Reenen 2007), stemming from concerns about the limitations of findings derived from aggregated metrics (Reynolds et al. 2005), due to aggregation bias or loss of variation (Higon et al. 2010). Research on hotels similarly found that aggregated productivity metrics obscured the performances of different departments (Brown and Dev 2000), which conceivably can operate in contrasting directions (Baker and Riley 1994), not least because there tend to be important differences in operating conditions at this scale. There are also strong temporal variations in demand for hotel services, often posing different challenges at departmental level in terms of managing labour inputs. This is rarely analysed in productivity studies because secondary, and indeed virtually all primary, survey data tend to be cross-sectional snapshots or annual averages; similar issues exist in retail productivity studies (Higon et al. 2010). In contrast, this paper examines hotel performance for the establishment and the two major constitutive departments: Rooms, and, Food and Beverage. These account for most hotel operations (Ball et al. 1986; Brown and Dev 1999; McMahon 1994; Wong 2004), and more than $90 \%$ of total average revenue in this case study.

\subsection{Flexibility and Migrant Labour}

Managerial practices constitute an important strand in the generic literature on the role of labour as a determinant of productivity (Fox and Smeets 2011; Syverson 2011). Bloom and van Reenen's $(2007,2010)$ benchmark studies of medium sized companies related respondents' subjective reporting of the importance of management practices to annualised output data. They 
found a statistically significant and non-trivial relationship between a range of management practices and performance measures, including flexibility, which is the focus of this paper. Other studies provide supporting evidence such as Ketkar and Sett's (2005) study of flexible HR practices in India.

Flexibility is an important management practice in an increasingly competitive environment (Miller and Shamsie 1996) and is likely to be heterogeneous within companies, varying across establishments, and across departments, reflecting both variations in the quality of management and local labour market conditions. Flexibility has many different meanings (Sethi and Sethi 1990) but, given our focus on labour performance, this paper examines labour flexibility, or work flexibility (Dreyer and Grønhaug 2004). Numerical (volume changes) and functional (redistribution between functions or departments) flexibility (Atkinson 1984) are considered to be the prevalent flexibility strategies in hotels (Lockwood and Guerrier 1989).

There are two main sources of numerical flexibility: internal and external. External numerical flexibility involves a basic divide between permanent and temporary workers (Boockmann and Hagen 2001) who are assumed to have different terms and conditions, and therefore costs, including investment in training (Saint-Paul 1996). Empirical evidence is relatively thin, even in the generic literature, but the performance of the two groups of workers depends on both wage differentials, and the balance of generic versus firm-specific skills and experience (Amiti and Wei 2006). The second main source of numerical flexibility is internal, that is temporal flexibility amongst the firm's permanent employees via one of several means including zero-hours contracts, part time workers, flexi time, compressed time, annualised hours, term time working, time-off-in-lieu, job sharing, overtime and shift working (Bryson 2007; Dench et al. 2006). The marginal costs of additional training for such workers are close to zero, and they have firm-specific skills. 
Bryson (2007: 8), following Hempell and Zwick (2005), broadly defines functional flexibility as 'doing tasks beyond the employees' immediate primary job. Research on functional flexibility has usually focussed on the transfer of labour between departments or roles, exemplified here by switching between the rooms and food \& beverage departments of hotels. The costs and outputs of functional flexibility depend on the differences in wages between the sending and receiving departments (often ignored), training required to work in another department, and the complexity (or the learning times and costs) of the tasks involved. Numerical and functional flexibility can be complements or substitutes, and they may overlap: for example, temporary workers may be required to work across different roles or departments, while permanent workers may be simultaneously numerically and functionally flexible. Managers tend to view these as complementary and seek 'flexibility from both sides' (White et al. 2004: 44), although strategies depend on the importance attached to labour skills and to operational conditions (Hempell and Zwick 2005). Interestingly, however, Puig-Roca et al (2008) in a study of Spanish industrial firms found there was a substitution effect between external and internal numerical flexibility, and that using both simultaneously did not necessarily improve performance.

There is limited systematic and detailed evidence on the implementation of flexibility and productivity practices over time in any sector, but this is particularly important in hotels, and tourism generally, because of highly variable demand conditions. Lockwood and Guerrier's (1989) survey of major hotel groups in the UK found that although they adopted both numerical and functional flexibility, the former was more important. That study was undertaken in 1989, before widespread introduction of zero-hours contracts to control costs (Berg et al, 2014). Nickson (2010) also found the main focus was on numerical flexibility and that functional flexibility mainly provided short term labour cover. Warhurst and Nickson (2007) also provide evidence of the importance of numerical and functional flexibility in their 
research on housekeepers. None of these studies had access to data on actual hours worked, and instead utilised secondary sources or ad hoc surveys which mostly relied on annual means or the simple absence or presence of such practices, rather than capturing the actual implementation of flexible working.

The relationships between performance and labour flexibility, which are the focus of this paper, depend on the costs and effectiveness (reflecting skill requirements) of different forms of flexible working, and the skills of managers in matching this (flexible) labour supply to demand. There is still limited research on the relationship between labour flexibility and productivity or performance. Bloom and van Reenen (2007) provide one of the more convincing generic studies, examining a range of work organization practices and incentives, including job design, which incorporated flexibility of working. They found a strong correlation between these management practices and various firm performance indicators. Other studies provide more indirect evidence. For example, the study conducted by Michie and Sheehan (2005) examines the relationship of HR practices including external labour flexibility (proportion of part-time, temporary contracts or seasonal/casual contracts) to labour productivity, in UK manufacturing and service-sector firms. The results showed the negative effect of external flexible labour on productivity, due to the notion of pursuing a cost-based strategy as opposed to enhancing the innovation and quality of the services. Koch and McGrath (1996) concluded that firms that invested in training were more likely to have higher productivity, which implies that external numerical flexibility is a barrier to higher productivity.

Bloom and van Reenen (2007) were unable to deconstruct work flexibility into its different components. This is important because although earlier researchers contended there was a negative relationship between flexibility and firm performance (Gustavsson 1984; Son and Park 1987), separate consideration of numerical and functional flexibility provides a more nuanced conclusion. Functional versus numerical flexibility involve different wage costs and 
skills availability (both task and firm specific), but the effects are likely to be highly contingent on the nature of the production, demand and skills requirements. Unsurprisingly, therefore, the empirical evidence is inconclusive. Some studies have found that numerical flexibility is associated with poorer performance and others that functional flexibility is associated with enhanced performance (Michie and Sheehan 2001, 2005; Chadwick and Cappelli 2002). This argument has been presented in a consistent manner in the context of the European service sector. Research investigating the Dutch market illustrates that while internal flexibility (or functional flexibility) leads to sales and employment growth, external flexibility (or external numerical flexibility) does not generate any notable outcome (Kleinknecht et al. 2006). A similar pattern has also been identified in the Italian market, where firms using higher shares of numerically flexible labour, experience lower labour productivity growth due to a large personnel turnover rate (Lucidi and Kleinknecht 2010). The study conducted by Arvanitis (2005) assessing the effect of labour flexibility on productivity and innovation for Swiss enterprises shows that different types of flexibility play different roles in predicting productivity: for instance, the positive influence of functional flexibility (team compensation), and the negative effect of numerical flexibility (i.e., part-time work). However, others found no evidence of any relationship between numerically flexible working and labour productivity (Bryson 2007). Interestingly, a study of the fishing industry (Dreyer and Grønhaug, 2004) found that those firms which developed different forms of flexibility in the face of different uncertainty factors could avoid consequential productivity losses.

The mixed evidence partly reflects the heterogeneity of some samples, and different measures of flexibility and productivity. There are very few studies of flexibility and performance or productivity in tourism and hospitality. Li and Prescott (2010) found a positive association between internal numerical flexibility (part time hours) and productivity in the Canadian tourism industry. Other researchers have also sought to incorporate work flexibility 
into productivity studies (Baker and Riley, 1994; Kappa, Nitschke, and Schappert 1997; Thompson, 1998; Soltani and Wilkinson 2010), but faced severe data constraints. Above all, there remains a significant gap in our understanding of the relationships between the implementation of different forms of work flexibility and productivity or performance in hotels.

\subsection{International Migrant Workers}

There are three main reasons why employing migrants may impact on productivity and performance. First, they may differ from non-migrant workers in terms of their skills and experience. Although there is mixed evidence as to whether international migrants have more or less human capital than non-migrants (Barwell 2007: 55), recent evidence suggests that, because migration is a self-selecting process, migrants do have higher levels of human capital (Chiswick 2000; Dustmann and Weiss 2008). There is also the question of the duration of the migration period, as initially migrants may lack the requisite nationally specific human capital (language skills, cultural expectations of customers etc.) to utilise their skills fully (Chiswick, Lee, and Miller 2005). Indeed, they may move into sectors such as hotels, as low wage, shortterm 'stepping stones' to better paid, more skilful jobs in the medium term (Williams 2009; Tilly and Tilly 1997).

Second, they may have different attitudes to work, for cultural reasons, or because their reference working conditions are different to those of non-migrants' (Scott 2013; Blanchflower, Saleheen, and Shadforth 2007; Dustman and Weiss, 2008). Employers seek out labour “... that accepts the management's wishes with the minimum of bridling' (Waldinger and Lichter 2003:143). These 'wishes' may include flexible working, and migration status may imply 'suitability for subordination'. A UK Home Office study (Dench et al. 2006) empirically substantiates this argument: employers in several sectors, including hospitality, reported favourably on the general attitudes and work ethics of migrants compared to non-migrants. 
Their turnover was lower, and they had a greater propensity to work longer and flexible hours. Migrants are also reported as being better able to perform in customer-facing roles (Dyer, McDowell, and Batnitzky 2008; Scott, 2013) and in repetitive routine tasks (Waldinger and Lichter 2003), both of which characterise hotels (Janta et al 2011).

A third argument centres on wage differentials. Migrants, because of their lower wage reference point, are willing to work for lower wages than non-migrants (Piore 1979; Blanchflower et al. 2007; Dustman and Weiss 2008). Therefore, if their physical output per hour is the same as non-migrant workers, this will result in stronger financial performance, although not physical performance.

There is limited and fragmented evidence on the relationship between migrant employment and productivity. Kangasniemi et al. (2009), using growth accounting models, estimate that, in the UK, 1996-2005, the employment of migrants generally contributed $0.29 \%$ growth, but this was substantially higher in hotels and restaurants $(0.73 \%)$. Using a production function approach, the use of migrant labour in Spain was associated with lower productivity, while in the UK there was a positive but insignificant association (Kangasniemi et al. 2009). In Canada, Li and Prescott (2010) found a positive association with productivity. While the research broadly indicates a positive association between productivity and the employment of migrants, most researchers were unable to address heterogeneity effects across individual firms, establishments or departments.

Turning to hotels, Markova et al.'s (2013) survey of managers of small and medium sized hotels in London found that migrants were valued both because they were willing to work for lower wages and because they possessed positive working competencies such as reliability, commitment, and willingness to work flexibly compared to non-migrants. Lucas and Mansfield (2010) also found that hospitality employers had multiple motives for employing migrant workers. However, these authors did not analyse the impacts of migrant employment on 
performance, and while they examined flexible working by migrants, they relied on crosssectional surveys of managers' subjective evaluations.

\section{Methodology}

This paper had access to a unique data set for 25 establishments in a single hotel company including hourly records for employment and weekly records for outputs, which have been aggregated to a monthly basis over an eight year period. These provide exceptionally detailed data on the relationships between labour and employment practices and performance, rather than relying on subjective estimates by managers, or on annual average returns. Controlling for heterogeneity by examining a single hotel company is important because management practices which target productivity and performance enhancement are likely to be firm specific (Wall and Wood 2005; Siebers et al. 2007). Focussing on a single company allows a measure of control for the institutional environment within which individual hotels (and departments within these) manage employment practices and overall performance. Even within this single company, however, the average output per hour of labour input (using financial measures) in the top decile was almost double that in the bottom decile of hotels (2.19 compared to 4.29).

\subsection{The Model}

To address the research questions outlined earlier, labour performance is modelled as a linear function of numerical and flexible working practices, migrant employment and other controls given by the equation:

$\operatorname{lnperf}_{i, t}=\mu_{i}+\gamma_{t}+\beta^{\prime} \ln x_{i, t}+\varepsilon_{i, t}, i=1, \ldots, 25$ and $t=2005: M 1,2005: M 2, \ldots, 2013: M 12$ (i) where $i$ and $t$ represent individual hotels, the cross-sectional units, in the sample and time period respectively; prefix to variables $\ln$ denotes natural logarithms of variables ${ }^{\mathrm{i}}$; perf is labour 
performance, constituting a vector of both physical and financial measures of establishment and departmental performance.

Traditional measures of labour productivity are based on the relationship between gross output or value added and the numbers of hours worked, which is between financial outputs and physical inputs. Given the micro-level data available to the project, and the aim of comparing financial and physical indicators, this paper explores two contrasting measures of labour performance. At the establishment level, financial performance is defined as the ratio of financial revenues - gross revenues from rooms, food and beverage sales, leisure and other activities - to labour costs incurred in generating these revenues. Physical performance is defined as the ratio of physical output - occupied room nights or food and beverage covers to labour hours used in generating the output. Physical performance can only be measured at departmental level, as the aggregation of largely heterogeneous outputs would be required to arrive at establishment physical productivity; the quality and size of rooms can however be considered to be relatively homogeneous in a highly branded hotel chain.

Analogous measures of financial and physical performance apply to the core departments, rooms and food and beverage; see Table 1 for an overview of their constitutive micro-departments; $\mu_{i}$ is the unobserved hotel specific time invariant effect; $\gamma_{\mathrm{t}}$, measured as year dummies covering the months the data are observed, is the time fixed effect capturing time-varying omitted variables and stochastic trends common to all hotels $;{ }^{\mathrm{ii}} \beta^{\prime}$ is a vector of slope parameters to be estimated; $x_{i, t}$ is a vector of measurable variables explaining productivity including the targeted regressors - numerical flexibility, functional flexibility and migrant employment - as well as other controls such as training cost and gender, recognizing the cost implications of gendered divisions of labour. Data were not available for other potentially important variables, such as education, and work experience outside the firm. A dozen binary variables in the vector 'month1 (January)-month12 (December)' control for seasonal variation 
in performance. Another binary variable "econcrisis" captures the differential in productivity between the $2008+$ economic crisis and non-crisis periods; and $\varepsilon_{i, t}$ is a random error term.

Table 1. Categorisation of Departments

\begin{tabular}{|c|c|c|}
\hline Rooms Department & $\begin{array}{c}\text { Food and Beverage } \\
\text { Department }\end{array}$ & Establishment \\
\hline $\begin{array}{ll}\text { - } & \text { Reception and } \\
\text { - } & \text { Poncierge/switchboard } \\
\text { - } & \text { Nights/night porters } \\
\text { - } & \text { Room sales } \\
\text { - } & \text { Housekeeping supervisors } \\
\text { - } & \text { Room attendants/cleaning } \\
\text { - } & \text { Public area cleaning and } \\
\text { - } & \text { linen porters } \\
\text { - Laundry }\end{array}$ & $\begin{array}{ll}\text { - } & \text { Restaurant } \\
\text { - } & \text { Bar } \\
\text { - } & \text { Room service } \\
\text { - } & \text { Restaurant food and bar } \\
\text { - } & \text { Cellar } \\
\text { - } & \text { Chefs and kitchen } \\
& \text { porters } \\
\text { - } & \text { Leisure F\&B }\end{array}$ & $\begin{array}{l}\text { Rooms and Food and Beverage } \\
\text { plus residual departments such } \\
\text { as: } \\
\text { - Conference, banqueting } \\
\text { and events } \\
\text { - Finance } \\
\text { - Administration } \\
\text { - Management } \\
\text { - Maintenance } \\
\text { - Leisure Staff } \\
\text { - Leisure- snow sport } \\
\text { - Ski hire etc. }\end{array}$ \\
\hline
\end{tabular}

The following proxies are employed for the vector of regressors in the model above.

i. Numerical Flexibility: Most previous research has used measures such as part time working as a proxy for numerical flexibility, but this does not capture the actual variation in hours worked over time. The term part time is also ambiguous in terms of the hours worked. This paper designs an index that captures the variation in which employees actually work numerically flexibly over time. This variable, termed 'variance index', is defined as the ratio of the differential between an employee's monthly hours and their annual monthly average hours to the annual monthly mean hours. This indicates the extent to which an employee is numerically flexible relative to their annual monthly average hours. Aggregating this statistic over all employees and dividing by the number of employees produces a ratio of time-demeaned hours to annual mean hours. Mathematically, the variance index is 
defined as: $\Sigma\left[\left(\mathrm{x}_{\mathrm{i}}-\mu_{\mathrm{i}}\right) / \mu_{\mathrm{i}}\right] / \mathrm{n}$, where $\mathrm{x}_{\mathrm{i}}, \mu_{\mathrm{i}}$ and $\mathrm{n}$ stand for an employee's monthly working hours, average monthly working hours and number of employees in the sample, respectively.

The richness of the dataset provides an opportunity to use a second measure of numerical flexibility - the share of zero contract employee hours to total hours by zero and permanent-contract staff. The use of zero-contract employees gives employers greater flexibility to vary or adjust labour hours to move in tandem with demand or respond to staff supply shortages (Berg et al. 2014), which should have particular implications for financial performance.

ii. Functional Flexibility: At the establishment level, this is defined as the ratio of hours of inter-departmental employee transfers across all micro-departments in the hotel - front desk, bar, conference and banqueting, leisure, housekeeping etc. - to total employee hours recorded by the establishment. For rooms and reception departments (thereafter, 'rooms'), this is defined as the ratio of hours of employee imports from all other departments to total hours in rooms department. An analogous index is computed for the food and beverage department. An index close to zero denotes a low level of inter-departmental employee transfers, hence functional flexibility. As with numerical flexibility, the measure is based on actual hours worked per month.

iii. Migrant and UK Labour: The ratio of hours worked by migrant (UK) employees to total hours worked by migrant and UK staff per month in the establishment, and core departments, is used as a proxy for migrant (UK) labour.

iv. Female and Male Labour: The share of female (male) hours to total hours by all workers per month in the establishment and the two core departments controls for 
gender in the estimations. The variable's coefficient provides the marginal effect of each gender's hours on productivity.

v. Training Cost: Total monthly expenditures on training programmes in the establishment, and departments, proxies for staff training.

vi. Economic Crisis: The binary variable "econcrisis" captures the differential in productivity between the 2008+ economic crisis and non-crisis periods: econcrisis $=1$ and econcrisis $=0$ in the crisis versus pre-and-post crisis periods respectively. The crisis, defined as two consecutive quarters of negative economic progress, is considered to have commenced in the second quarter of 2008 and ended at the second quarter of 2009 (see ESRC 2009). Hence, the period covers 2008:M42009:M6. The coefficient of this variable gives the differential in productivity between the crisis period and the base period, pre-and-post crisis period.

Incorporating the variables described above into equation (i), an expanded version of the equation is:

$$
\begin{aligned}
& \operatorname{lnperf}_{i, t}=\mu_{i}+\gamma_{t}+\beta_{1} \ln \text { numflex } \\
&+\beta_{3} \ln \beta_{2} \operatorname{lnfuncfle} x_{i t} \\
&+\beta_{4} \ln \text { shareofmigranthours }(\text { shareofUKhours })_{i t} \\
&+\beta_{5} \ln \text { shareoffemaurs }(\text { shareofpermhours })_{i t} \\
&+\beta_{7} \text { econcrisis }_{i t}+\beta_{8} \text { month }_{1 i}+\beta_{9} \text { month }_{i t}+\cdots+\beta_{19} \text { month }_{i 2} 2_{i t}+\varepsilon_{i, t}, \\
& i=1, \ldots, 25 \text { and } t=2005: M 1,2005: M 2, \ldots, 2013: M 12
\end{aligned}
$$

Standard OLS panel econometric estimation procedures, fixed and random effects models, are used to estimate the model in equation (ii). The difference between the two estimators lies in their treatment of the unobserved effect, $\mu_{i}$. Fixed effects assumes correlation between the unobserved effects and explanatory variables, while random effects assumes no correlation between these parameters. Hausman (1978) developed a test for the choice of the appropriate estimator given these assumptions. Most empirical applications of panel 
econometric procedures employ the fixed effects estimator. It is almost always more appropriate than random effects for policy analysis using aggregated data (Wooldridge 2008).

\subsection{Data Summary}

All data employed for the paper's estimations are obtained from Eproductive, a management systems company which provides software to client hotels where information such as employee scheduling, employee wage rates, room nights, food and beverage covers, revenues from room nights, food and beverage and other activities are recorded on a periodic basis: data are recorded for all workers on an hourly basis, and output data as a weekly summary. ${ }^{\mathrm{iii}}$ These are aggregated to monthly series. The period covered spans from 2005:M1-2013:M12.

Table 2 presents summary statistics (means) of the variables employed for the estimations. Aggregating all revenues (from rooms, food and beverage, and other outputs), the mean indicator of hotel-wide financial performance is $£ 3.28$. This implies a mean revenue of $£ 3.28$ per $£ 1$ unit of labour cost. As noted earlier, combining services and outputs resulting from different hotel activities involves pooling heterogeneous services. This aggregation has been a recurrent problem in previous studies using physical measures of productivity, underlining the value of this paper's departmental-level analysis. 
Table 2. Data Summary

\section{Variable Names}

Physical performance (output / labour hour)

Mean All Depts.

Mean Rooms Dept. Mean F\&B Dept.

Financial performance (revenue / labour cost)

0.9020

3.2777

0.7272

1.4592

Revenue per room (f)

Numerical flexibility (variance indicator)

$-$

5.9974

3.2453

Functional flexibility index

0.2468

53.5233

Share of migrants hours in total hours

0.0962

0.2474

0.0431

0.2888

0.2559

0.3316

0.0268

Migrants labour cost per hour

6.14

5.96

0.2854

UK labour cost per hour

7.44

6.39

5.40

0.1233

0.1259

5.95

Share of zero contract employee hours in total hours

5.1604

Permanent contract employees' wage cost per hour

7.43

5.6009

0.1841

0.4921

6.36

4.9826

Share of female hours in total hours by females and males

6.75

0.6873

5.97

Female labour cost per hour

7.35

6.18

0.3377

Male labour cost per hour

2912.15

6.44

5.35

Training cost 
The summary statistics in Table 2 portray the heterogeneous input-output relationships in the two core departments. For instance, the table indicates a higher mean, but nonstandardised, physical performance in food and beverage than rooms, while the corresponding financial measure of productivity shows a reverse comparison. A unit labour cost generates $£ 3.25$ and $£ 6.00$ worth of services in the former and latter departments respectively, underlining the different perspectives provided by these two measures. The physical performance measures of the two departments cannot be directly compared. Rooms department has a higher share of migrant hours and labour is less numerically but more functionally flexible than food and beverage. Migrant hourly labour costs are generally less than those of local employees', and, zero-contract and female staff also cost less than permanent-contract and male staff at both establishment and departmental levels respectively. These cost measures are not standardised across specific jobs. The table also contains summaries for other relevant variables, and generally reinforces the value of the disaggregated departmental level perspective.

\section{Findings and Discussion}

The paper's estimations are presented in Tables 3, 4 and 5 for the establishment, rooms and food and beverage departments respectively. The Hausman test indicated that the fixed effects estimator is more appropriate than random effects in all models considered at the establishment and departmental units of analysis. Hence, the following results are obtained by fixed effects estimations. For the results of Table 4 and 5, coefficients are estimated for physical [a] and financial [b] measures of performance as the left-hand-side variables in the two departments respectively. Heteroscedasticity robust standard errors are reported in parentheses next to coefficient estimates. 
Table 3. Results of Fixed Effects Regression: Establishment

\begin{tabular}{lc}
\hline Explanatory Variables & Dependent Variable $^{\mathbf{1}}$ \\
\hline & {$[\mathbf{1}]$ InPerf_fin } \\
\cline { 2 - 2 } Numerical flexibility (variance indicator) & Estimated Coefficients \\
\cline { 2 - 2 } Functional flexibility index & $0.0262(0.0538)$ \\
Share of migrants hours in total hours & $0.0261(0.0189)$ \\
[Share of UK hours in total hours] & $0.0618^{*}(0.0211)$ \\
Share of zero contract hours in total hours & {$\left[-0.1340^{* * *}(0.0729)\right]$} \\
[Share of permanent contract hours in total hours] & $0.0401^{*}(0.0118)$ \\
Share of female hours in total hours & {$\left[-0.7905^{*}(0.1284)\right]$} \\
[Share of male hours in total hours] & $0.2890^{*}(0.0914)$ \\
Training cost & {$\left[-0.3545^{*}(0.0860)\right]$} \\
econ_crisis & $0.0143(0.0092)$ \\
Month2 (February) & $-0.0996^{* *}(0.0460)$ \\
Month3 (March) & $0.1212^{* *}(0.0558)$ \\
Month4 (April) & $0.2526^{*}(0.0391)$ \\
Month5 (May) & $0.2668^{*}(0.0411)$ \\
Month6 (June) & $0.2937^{*}(0.0451)$ \\
Month7 (July) & $0.3184^{*}(0.0502)$ \\
Month8 (August) & $0.3147^{*}(0.0432)$ \\
Month9 (September) & $0.3219^{*}(0.0437)$ \\
Month10 (October) & $0.3393^{*}(0.0443)$ \\
Month11 (November) & $0.2274^{*}(0.0433)$ \\
Month12 (December) & $0.1609^{*}(0.0436)$ \\
constant & $0.3357^{*}(0.0431)$ \\
Observations & $1.4702^{*}(0.1291)$ \\
Groups (hotels) & 2019 \\
F-test & 24 \\
Adjusted R & 0.0000 \\
\hline Note ${ }^{2}$ The ders & $0.1813(0.2012)$ \\
\hline
\end{tabular}

Note: ${ }^{I}$ The dependent variable combines the productivity values of rooms, $\mathrm{F} \& \mathrm{~B}$, and other departments. Standard errors reported in parentheses beside coefficient estimates.

$* p<0.05 ; * * p<0.01 ; * * * p<0.001$

Results for the establishment, model [1] (Table 3), indicate a positive association between financial performance and numerical and functional flexibility. These associations are insignificant as the variables are not backed by either the individual t-test or F-test of joint statistical significance. However, a one percent increase in share of migrant hours is significantly associated with a 0.06 percent increase in financial performance. Also, a one percent increase in the share of zero-contract and female hours is significantly associated with 0.04 and 0.29 percent increases in financial performance, respectively. When rerunning the benchmark models, substituting the share of migrant hours, zero-contract hours and female hours in the benchmark model with their analogous measures - share of UK hours, permanent- 
contract hours and male hours - the significant results show that a one percent increase in the latter shares leads to $0.13,0.79$ and 0.35 percent fall in productivity respectively. ${ }^{\text {iv }}$ The variables controlling for fluctuations in demand conditions - the monthly binary variables are jointly significant in the estimations at establishment and departmental levels, hence, are not commented on further in these results.

The coefficients of determination, adjusted $\mathrm{R}^{2} \mathrm{~s}$, reported in model [1] denotes that the explanatory variables explain 18.1 percent of the variation in log of financial performance. Moreover, the F-stats denotes that the explanatory variables are jointly significant.

Models [2a] and [2b] present results for rooms department. Most labour management variables in model [2a], for physical performance, are not significant. The only exceptions are shares of permanent contract and male hours. A one percent increase in these variables leads to a fall in physical performance by 0.37 and 0.09 percent, respectively. Relative to model [1], these variables exert the same directional effects on productivity albeit at different magnitudes and measures of performance.

Model [2b] presents results for financial performance in rooms department. Functional flexibility exerts a negative effect on rooms financial performance. A one percent increase in this variable leads to a 0.02 percent decrease in rooms' financial performance. Whilst migrant employment is a significant and positive determinant of financial performance at the establishment level, this variable is marginally insignificant (at the ten percent level) in rooms department. This variable's coefficient shows that a one percent increase in the share of migrant hours is associated with a 0.06 percent increase in performance. The share of female hours in model [2b] exerts the same positive directional effect on financial performance of rooms department as in the establishment level model. A one percent increase in this variable increases rooms' financial performance by approximately 0.23 percent. Conversely, a one percent increase in the share of UK, permanent-contract and male hours leads to $0.12,0.29$ and 
0.13 percent decreases in performance, respectively. These results again illuminate differences in hourly labour costs.

Table 4. Results of Fixed Effects Regression: Rooms Department

\begin{tabular}{|c|c|c|}
\hline \multirow{3}{*}{ Explanatory Variables } & \multicolumn{2}{|c|}{ Dependent Variables $^{1}$} \\
\hline & [2a] InPerf_phy & [2b] lnPerf_fin \\
\hline & Estimated Coefficients & Estimated Coefficients \\
\hline Numerical flexibility (variance indicator) & $0.0479(0.0537)$ & $-0.0469(0.0504)$ \\
\hline Functional flexibility index & $-0.0035(0.0103)$ & $-0.0246^{* *}(0.0115)$ \\
\hline Share of migrants hours in total hours & $0.0382(0.0409)$ & $0.0561(0.0359)$ \\
\hline [Share of UK hours in total hours] & {$[-0.0358(0.0493)]$} & {$[-0.1170 * *(0.0517)]$} \\
\hline Share of zero contract hours in total hours & $0.0072(0.0149)$ & $0.0003(0.0109)$ \\
\hline [Share of permanent contract hours in total hours] & {$[-0.3660 *(0.1086)]$} & {$[-0.2913 *(0.1083)]$} \\
\hline Share of female hours in total hours & $0.1425(0.1370)$ & $0.2255 * *(0.1124)$ \\
\hline [Share of male hours in total hours] & {$[-0.0906 * *(0.0360)]$} & {$[-0.1295 *(0.0374)]$} \\
\hline Training cost & $-0.0018(0.0096)$ & $-0.0041(0.0092)$ \\
\hline econ_crisis & $-0.0238(0.0528)$ & $-0.0202(0.0435)$ \\
\hline Month2 (February) & $0.0806(0.0647)$ & $0.1219 * *(0.0598)$ \\
\hline Month3 (March) & $0.1453 *(0.0535)$ & $0.2177 *(0.0537)$ \\
\hline Month4 (April) & $0.2424 *(0.0528)$ & $0.2125 *(0.0503)$ \\
\hline Month5 (May) & $0.1753 * *(0.0702)$ & $0.1875 * *(0.0734)$ \\
\hline Month6 (June) & $0.2677 *(0.0546)$ & $0.3407 *(0.0535)$ \\
\hline Month7 (July) & $0.2452 *(0.0608)$ & $0.3072 *(0.0616)$ \\
\hline Month8 (August) & $0.2991 *(0.0489)$ & $0.3259 *(0.0531)$ \\
\hline Month9 (September) & $0.2849 *(0.0532)$ & $0.3133 *(0.0573)$ \\
\hline Month10 (October) & $0.2109 *(0.0543)$ & $0.2381 *(0.0540)$ \\
\hline Month11 (November) & $0.1595 *(0.0611)$ & $0.2119 *(0.0495)$ \\
\hline Month12 (December) & $0.1125^{* * *}(0.0646)$ & $0.1046^{* * *}(0.0630)$ \\
\hline Constant & $-0.1548(0.2401)$ & $1.5924 *(0.1462)$ \\
\hline Observations & 964 & 966 \\
\hline Groups (hotels) & 25 & 25 \\
\hline F-test & 0.0000 & 0.0000 \\
\hline Adjusted $\mathrm{R}^{2}$ & $0.3658(0.3987)$ & $0.2703(0.3081)$ \\
\hline
\end{tabular}

Note: ${ }^{I}$ The dependent variable focuses on rooms department.

Standard errors reported in parentheses beside coefficient estimates.

$* p<0.05 ; * * p<0.01 ; * * * p<0.001$

The adjusted $\mathrm{R}^{2} \mathrm{~s}$ in models [2a] and [2b] denote that the explanatory variables explain 36.6 and 27.0 percent of the variation in log of physical and financial performances in rooms 
department respectively, both of which are higher than in the establishment level model. Fstats indicate that the regressors are jointly significant (see Table 4).

Models [3a] and [3b] present results for food and beverage department. In [3a], a notable difference compared to rooms and the establishment level models is that both numerical and functional flexibility are negative and significant determinants of physical performance. Increasing numerical and functional flexibility by one percent leads to a 0.13 and 0.02 percent decrease in food and beverage's physical performance. Other results in model [3a] indicate that a one percent increase in the share of female hours leads to a rise in performance by 0.11 percent while share of male hours, exerts the usual negative effect: increasing male hours by one percent leads to a 0.37 percent fall in physical performance. Again, the crisis variable provides evidence of performance being lower in the crisis period (by about 11.7 percent) relative to the pre-and-post-crisis periods

Model [3b] presents the analogous results for food and beverage financial performance. As in this department's physical performance, functional flexibility also exerts a negative and significant effect on financial productivity. A one percent increase in functional flexibility leads to 0.02 percent decrease in financial performance. The share of female hours in this department exerts a positive effect while the shares of permanent contract and male hours exert the opposite effect. This finding is consistent for the measure of financial performance across the establishment, rooms and food and beverage departments. Again, these results buttress the mean estimates presented by the summary statistics, that zero-contract and female labour are generally lower cost than permanent-contract and male labour respectively. The adjusted $\mathrm{R}^{2} \mathrm{~S}$ reported in [3a] and [3b] imply that the explanatory variables in the models explain 29.8 and 23.9 percent of the variation in log of physical and financial performance indicators in food and beverage respectively. F-stats denote that the explanatory variables are jointly significant. 


\begin{tabular}{lcc}
\hline & [3a] lnPerf_phy & [3b] lnPerf_fin \\
\cline { 2 - 3 } Numerical flexibility (variance indicator) & Estimated Coefficients & Estimated Coefficients \\
\cline { 2 - 3 } Functional flexibility index & $-0.1318^{* *}(0.0661)$ & $0.0146(0.0539)$ \\
Share of migrants hours in total hours & $-0.0235^{* *}(0.0114)$ & $-0.0156^{* * *}(0.0088)$ \\
[Share of UK hours in total hours] & $0.0219(0.0238)$ & $-0.0202(0.0189)$ \\
Share of zero contract hours in total hours & {$[0.0333(0.0602)]$} & {$[0.0531(0.0492)]$} \\
[Share of permanent contract hours in total hours] & $0.0032(0.0139)$ & $0.0083(0.0110)$ \\
Share of female hours in total hours & {$[-0.0003(0.0946)]$} & {$\left[-0.1820^{* *}(0.0760)\right]$} \\
[Share of male hours in total hours] & $0.1082^{* * *}(0.0579)$ & $0.1431^{*}(0.0478)$ \\
Training cost & {$\left[-0.3730^{*}(0.1163)\right]$} & {$\left[-0.3608^{*}(0.0875)\right]$} \\
econ_crisis & $0.0154(0.0131)$ & $0.0059(0.0086)$ \\
Month2 (February) & $-0.1173^{* *}(0.0463)$ & $-0.0502(0.0448)$ \\
Month3 (March) & $0.0981(0.0671)$ & $0.0953(0.0591)$ \\
Month4 (April) & $0.1245^{* * *}(0.0681)$ & $0.2061^{*}(0.0522)$ \\
Month5 (May) & $0.1275(0.0798)$ & $0.2047^{*}(0.0521)$ \\
Month6 (June) & $0.1391 * * *(0.0737)$ & $0.2505^{*}(0.0568)$ \\
Month7 (July) & $0.1976^{*}(0.0728)$ & $0.3069^{*}(0.0541)$ \\
Month8 (August) & $0.1473^{* * *(0.0832)}$ & $0.2509^{*}(0.0570)$ \\
Month9 (September) & $0.2782^{*}(0.0668)$ & $0.2851^{*}(0.0521)$ \\
Month10 (October) & $0.3063^{*}(0.0610)$ & $0.3244^{*}(0.0502)$ \\
Month11 (November) & $0.2226^{*}(0.0665)$ & $0.2095^{*}(0.0540)$ \\
Month12 (December) & $0.1609^{* *}(0.0702)$ & $0.1956^{*}(0.0525)$ \\
Constant & $0.0335(0.0811)$ & $0.5369^{*}(0.0534)$ \\
Observations & $-0.1452(0.1504)$ & $0.9948^{*}(0.1160)$ \\
Groups (hotels) & 1,460 & 1,512 \\
F-test & 25 & 25 \\
Adjusted R & 0.0000 & 0.0000 \\
\hline Note'The & $0.2975(0.3216)$ & \\
\hline
\end{tabular}

Note: ${ }^{l}$ The dependent variable focuses on food and beverage department.

Standard errors reported in parentheses beside coefficient estimates.

$* p<0.05 ; * * p<0.01 ; * * * p<0.001$

In summary, our analysis reveals some notable similarities and differences in the effects

of regressors across departments and indicators of productivity (Table 6). Returning to the objectives set out in the introduction, there are three main points for discussion. 
Table 6. A Summary of the Results of the Regression Models

\begin{tabular}{|c|c|c|c|c|c|}
\hline \multirow{2}{*}{$\begin{array}{l}\text { Level } \\
\text { Measure }\end{array}$} & \multirow{2}{*}{$\begin{array}{c}\text { Establishment } \\
\text { Financial }\end{array}$} & \multicolumn{2}{|c|}{ Rooms } & \multicolumn{2}{|c|}{ Food and Beverage } \\
\hline & & Physical & Financial & Physical & Financial \\
\hline Numerical Flexibility Variance & - & - & - & $-\mathrm{ve}^{* *}$ & - \\
\hline Functional Flexibility & - & - & $-\mathrm{ve}^{* *}$ & $-\mathrm{ve}^{* * *}$ & $-\mathrm{ve}^{* * *}$ \\
\hline Migrant hours & $+\mathrm{ve}^{*}$ & - & - & - & - \\
\hline UK hours & $-\mathrm{ve}^{* * *}$ & - & $-\mathrm{ve}^{* *}$ & - & - \\
\hline Zero hours & $+\mathrm{ve}^{*}$ & - & - & - & - \\
\hline Permanent hours & $-\mathrm{ve}^{*}$ & $-\mathrm{ve}^{*}$ & $-\mathrm{ve}^{*}$ & - & $-\mathrm{ve}^{* *}$ \\
\hline Female hours & $+\mathrm{ve}^{*}$ & - & $+\mathrm{ve}^{* *}$ & $+\mathrm{ve}^{* * *}$ & $+\mathrm{ve}^{*}$ \\
\hline Male hours & $-\mathrm{ve}^{*}$ & $-\mathrm{ve}^{* *}$ & $-\mathrm{ve}^{*}$ & $-\mathrm{ve}^{*}$ & $-\mathrm{ve}^{*}$ \\
\hline Training cost & - & - & - & - & - \\
\hline Economic Crisis & $-\mathrm{ve}^{* *}$ & - & - & $-\mathrm{ve}^{* * *}$ & - \\
\hline
\end{tabular}

$\dagger p<0.10 ; * p<0.05 ; * * p<0.01 ; * * * p<0.001$

First, the findings indicate the complexity and multi-dimensional nature of flexibility (cf. Bloom and van Reenen 2007). Numerical flexibility exerts a negative and significant effect on the physical performance measure in food and beverage departments, but has no significant association with any of the other productivity measures at establishment or departmental level. However, numerical flexibility can be measured in many different ways (Sisson and Marginson 2003). Another measure of numerical flexibility, the share of zero contract labour, exerts a positive effect on establishments' financial productivity. This variable is not significant in either the rooms or food and beverage department. However, if the model is run, substituting the corresponding measure of permanent contract hours, then the latter exerts a negative effect on hotel-wide financial productivity and both measures of performance in rooms and food and beverage departments. The only exception is food and beverage physical productivity where the negative association is not statistically significant. The somewhat inconsistent findings for numerical flexibility may be due to the inclusion of the zero hours variable in the models. The 
variance and zero-contract hours indicators of numerical flexibility employed in the paper are partly related. The variation in hours of all employees captured by the variance indicator also includes variation in hours worked by zero-contract staff. Hence, the effect of these (somewhat) similar variables on productivity could be masked by the inclusion of both variables in the same model. The effect of the variance measure could be partly masked by the zero-contract variable and vice-versa.

Functional flexibility presents relatively consistent findings related to financial performance measures in the departments. It is a negative and significant determinant of financial performance in both departments. There is also a negative relationship with physical productivity in both departments but this is only significant for food and beverage. The negative relationship of functional flexibility with physical productivity in food and beverage reflects both the less effective performance of 'imported' labour compared to regular employees, as well as the higher costs of labour in rooms department and the residual departments in the hotel (implicit in the summary statistics, Table 2). The position with rooms is more complex. The lack of a significant relationship for physical productivity suggests there is no clear evidence that the imported staff are significantly less likely to be less efficient. This is consistent with the relatively limited skills required in servicing rooms, compared to say working in food and beverage. More surprisingly, initially, is the negative association with financial performance, as hourly labour costs are higher in rooms than in food and beverages, so that functional flex should reduce total labour costs. However, this may be due to $24 \%$ of the labour being imported from the residual departments, including administrative and management departments, which have substantially higher mean labour costs for UK workers (as implied by Table 2); further research is required to analyse functional flexibility at an even more disaggregated (subdepartmental) level. 
These findings are contrary to the broad, if tentative, consensus in the generic literature that numerical flexibility is associated with poorer performance and that functional flexibility is associated with enhanced performance (Bryson 2007; Michie and Sheehan 2001; 2005; Chadwick and Cappelli 2002). Those findings are based on relatively heterogeneous samples, and within the hotel sector most researchers have been unable to examine specific types of work flexibility, although pointing to a generally positive relationship with productivity (Jones and Siag 2009; Sigala et al. 2005). However, there is some evidence from tourism studies (Li and Prescott 2010) of a positive association between numerical flexibility and productivity. Echoing Dreyer and Grønhaug's (2004) comment, in a different context, hotels seems to have developed specific forms of numerical flexibility, including zero hours contracts, in the face of different uncertainty factors, and seem able either to benefit from performance enhancement, or at least to avoid consequential performance losses from these strategies. Functional flexibility has negative associations with both performance estimates in food and beverage departments, as well as rooms physical productivity. In summary, and confirming Berg, Bosch, and Charest (2014) study, which also focussed on a single firm, the type of flexibility strategy adopted by managers does matter.

Second, migrant labour only has a positive and significant relationship with financial performance in the establishment. Other coefficients of this variable are positive but insignificant in rooms and food and beverage departments; though this is marginal with respect to rooms financial performance. The corollary of this is that the employment of UK workers has negative coefficients for measures of financial performance in the establishment and rooms. This finding is broadly in line with general evidence on the positive contribution of migrant labour to productivity in the UK (Kangasniemi 2009), and Li and Prescott's (2010) findings specifically for tourism in Canada. As discussed in the literature review, the positive association between migrant employment and hotel-wide financial performance may be due to 
their greater human capital, lower costs (see Table 2) or work attitudes (Blanchflower et al. 2007; Dustman and Weiss 2008). The consistent negative associations between employment of UK workers and financial performance at establishment and rooms department signals the likely importance of labour cost differentials. The hotel-specific literature provides no clear evidence on the relationship of migration to productivity, but migrants' lower wage costs, and work attitudes, are valued by hotel managers (Markova et al. 2013; Lucas and Mansfield 2010). Human capital may also be important, but the only related measure in the data set is average weekly training expenditure, a measure of additional human capital formation, which is not differentiated by migrants versus UK employees. Further research is required on this issue beyond the constraints of these estimations.

Third, financial and physical performance measures produce different findings in the two departments. In rooms, functional flexibility is significant for financial but not for physical performance, while shares of UK hours and employment of women are also significant for financial but not for physical performance. In food and beverage, numerical flexibility is negatively associated with physical but not financial performance. The employment of permanent contract staff is negatively associated with financial but not physical productivity. ${ }^{\mathrm{v}}$ These differences, even within a highly specific study of a single company, indicate the inherent limitations of most existing research on hotel productivity which employs only financial measures, or composite measures (Anderson et al. 1999; Hu and Cai 2004; Sigala et al. 2005; Barros 2005). The choice of productivity measure really matters in hospitality as in other service sectors (Reardon and Vida 1998). Market imperfections are usually considered important in explaining differences between physical and financial productivity (Reynolds et al. 2005) in the generic literature, as are differences between new entrants and existing firms, but neither explanation would apply in a clear and consistent way across departments within a single firm. The differences between departments reinforce Brown and Dev's (2000) 
conclusion that firm or even establishment-level estimates of hotel productivity, can conceal major differences in departmental performances (Baker and Riley 1994).

\section{Conclusions}

Drawing on a detailed data set, which recorded the employment of workers on an hourly basis, by departments, over an eight year period, this paper has analysed determinants of labour performance at the establishment and department level for a single hotel firm (chain). This has allowed the paper to make three main contributions..

First, even within a single firm, performance and productivity relationships with determinant variables at the establishment level are not systematically evident at the departmental level. There is intra-establishment variance which, although it may be present in all sectors, is particularly marked in hotels where it is difficult to standardize the quality of outputs (meals served versus rooms serviced) and inputs (Gronroos and Ojasalo 2004), and demand is less predictable in food and beverage than in rooms. When analysing hotels considerable attention should be given to scale-specific effects in findings which are likely to be informed by aggregation bias (Higon et al. 2010).

Second, there are important differences between financial and physical measures of performance. This confirms earlier commentaries about technical issues relating to the measurement of productivity, both generally (Griffith and Harmgart 2005), and in hotels (Anderson et al 1999). Moreover, a comparative analysis which observes divergences and similarities in the estimates for financial versus physical performance can provide insights into the determinants of productivity, such as differences in skills requirements and wages between departments, as evident in respect of functional flexibility in this case study. 
Third, although work flexibility is an important determinant of performance, there is a need to deconstruct this broad concept (Sisson and Marginson 2003). Going beyond the established divide between numerical and functional flexibility, this paper has illustrated both overlaps and differences in the influence of zero-hours contract working as opposed to overall variance in all forms of numerically flexible working. The paper has also underlined the need for research on actual working hours, distributed over time (the interval in this paper was monthly), rather than relying on annual averages, or cross-sectional data. Dreyer and Grønhaug (2004: 484) commented that flexibility is a company-specific resource, but this paper demonstrates that such a resource is utilised differently across establishments, and departments, even within a single company. The reasons for the variations in the relationships between flexibility and performance across establishments and departments are beyond the scope of this paper, but are assumed to be related to the quality of management and local labour market conditions, neither of which are included in our data set, and must remain an object of future research.

Building on the methodology and findings of this paper, some directions for future research can be specified. There is clearly a need to deepen our understanding of the changing distribution of different forms of flexible working in hotels, and more generally in tourism, including how these vary not only between sectors and firms (Hempell and Zwick 2005) but also establishments and departments, and even sub-departments. The extent to which managers consider different forms of flexibility, or flexibility versus employment of migrants, to be complementary or substitutable also requires further analysis, probably utilising a mixture of modelling and qualitative methods. Furthermore, given the importance of balancing continuity and flexibility in the work force, there are presumably diminishing returns to flexible working, and this is an issue that requires further research, including the identification of whether there are critical thresholds in respect of the impact on performance. 
Additionally, while this paper has provided an indication of the positive contribution of migrants to performance - and with greater significance, the negative relationship with the employment of UK workers - migrants are a heterogeneous group. Their contributions to performance and productivity are likely to vary according to the duration of migration and employment in the company (influencing the acquisition of specific human capitals (Dustman and Weiss 2008), by nationality, by the sectors employed in, and their working patterns and attitudes. There is also a need to look at the wages of migrants and non-migrants not only at establishment and departmental level, but also within particular occupations.

Finally, it is worth noting that the fixed effects procedure used in this paper effectively estimated the relationship between performance and labour management practices. However, results obtained from this analysis preclude a causal interpretation of the effect of the independent variables on the dependent variables due to potential endogeneity bias in the estimations. A potential source of endogeneity bias is an assumed bi-directional correlation between performance and the right hand variables. For instance, as covered in the literature review, it is generally perceived that an increased numerical flexibility leads to an increase in productivity. However, in periods of low financial productivity or declining revenues, hotel managers may be forced to adopt more flexible working practices when labour is shed. Hence, there is likely to be a two way causation between performance and flexibility. In order to make causal effect interpretations of the effect of the regressors on the regressands, further studies will need to delve into the econometric exercise of investigating this or similar topics using instrumental variable and Generalised Method of Moments approaches. 


\section{References}

Amiti, M., and S. J. Wei. (2006). Fear of Outsourcing: Is It Justified? NBER Working Paper No. 10808, Cambridge: Mass.

Anderson, R. I., M. Fish, Y. Xia, and F. Michello. (1999). "Measuring Efficiency in the Hotel Industry: A Stochastic Frontier Approach”. International Journal of Hospitality Management, 18: 45-57.

Arvanitis, S. (2005). Modes of labor flexibility at firm level: Are there any implications for performance and innovation? Evidence for the Swiss economy. Industrial and Corporate Change, 14(6), 993-1016

Atkinson, J. (1984). Flexibility, Uncertainty and Manpower Management. Brighton Institute of Manpower Studies, University of Sussex, Report 89.

Baker, M., and M. Riley. (1994). "New Perspectives on Productivity in Hotels: Some Advances and New Directions.” International Journal of Hospitality Management, 13 (4): 297311.

Ball, S. D., K. Johnson, and P. Slattery. (1986). "Labour Productivity in Hotels: An Empirical Analysis.” International Journal of Hospitality Management, 5 (3): 141-47.

Barros, C. P. (2005). "Measuring Efficiency in the Hotel Sector." Annals of Tourism Research, 32 (2): 456-77.

Bartelsman, E., and M. Doms. (2000). "Understanding Productivity: Lessons from Longitudinal Microdata.” Journal of Economic Literature, 38(3): 569-94.

Barwell, R. (2007). “The Macro Economic Impact of International Migration." Bank of England Quarterly Bulletin, Q1: 48-59.

Berg, P., G. Bosch, and J. Charest. (2014). "Working Time Configurations: A Framework for Analyzing Diversity across Countries." Industrial and Labor Relations Review, 67: 805-37. 
Blanchflower, D. G., J. Saleheen, and C. Shadforth. (2007). The Impact of Recent Migration from Eastern Europe on the UK Economy. IZA Discussion Paper No. 2615.

Bloom, N., and J. van Reenen. (2007). "Measuring and Explaining Management Practices across Firms and Countries.” Quarterly Journal of Economics, 122 (4): 1341-408.

Bloom, N., and J. van Reenen. (2010). Human Resource Management and Productivity. London School of Economics, Centre for Economic Performance, Discussion Paper No. 982.

Boockmann, B., and T. Hagen. (2001). The Use of Flexible Working Contracts in West Germany: Evidence from an Establishment Panel. Mannheim: ZEW Discussion Paper No. 01-33.

Brown, J. R., and C. S. Dev. (1999). "Looking beyond RevPar: Productivity Consequences of Hotel Strategies." Cornell Hotel and Restaurant Administration Quarterly, 40: 23-33.

Brown, J. R., and C. S. Dev. (2000). “Improving Productivity in a Service Business: Evidence from the Hotel Industry." Journal of Service Research, 2 (4): 339-54.

Bryson, A. (2007). Temporary Agency Workers and Workplace Performance in the Private Sector. London School of Economics, Centre for Economic Performance, Manpower Human Resource Lab, Discussion Paper No. 3.

Chadwick, C., and P. Cappelli. (2002). Functional or Numerical Flexibility? Which Pays Off for Organizations? Management Department, The Wharton School, University of Pennsylvania, mimeo.

Chiswick, B. R. (2000). “Are Immigrants Favorably Self-Selected? An Economic Analysis.” In C. B. Brettell and J. F. Hollifield (eds), Migration Theory. London: Routledge, pp. $61-76$. 
Chiswick, B. R., Y. L. Lee, and P. Miller. (2005). "Longitudinal Analysis of Immigrant Occupational Mobility: A Test of the Immigrant Integration Hypothesis.” International Migration Review, 39 (2): 332-53.

David, J. S., S. Grabski, and M. Kasavana. (1996). "The Productivity Paradox of HotelIndustry Technology." Cornell Hotel and Restaurant Quarterly, 37 (2): 64-71.

Dench, S., J. Hurstfield, D. Hill, and K. Ackroyd. (2006). Employers' Use of Migrant Labour. Home Office Online Report 04/06, March. London: Home Office.

Dreyer, B., and K. Grønhaug. (2004). "Uncertainty, Flexibility and Sustained Competitive Advantage.” Journal of Business Research, 57: 484-94.

Dustmann, C., and Y. Weiss. (2008). "Return Migration: Theory and Empirical Evidence from the UK." British Journal of Industrial Relations, 45 (2): 236-56.

Dyer, S., L. McDowell, and A. Batnitzky. (2008). "Emotional Labour/body Work: The Caring Labours of Migrants in the UK's National Health Service.” Geoforum, 39: 2030-38.

ESRC (2009). Recession Britain: Findings from Economic and Social Research. http://www.esrc.ac.uk/_images/Recession_Britain_tcm8-4598.pdf.

Faggio, G., K. G. Salvanes, and J. van Reenen. (2007). The Evolution of Inequality in Productivity and Wages: Panel Data Evidence. Centre for Economic Performance London School of Economics and Political Science CEP Discussion Paper No 821.

Foster, L., J. Haltiwanger., and C. Syverson. (2008). "Reallocation, Firm Turnover, and Efficiency: Selection on Productivity or Profitability?" American Economic Review, 98 (1): 394-425.

Fox, J. T., and V. Smeets. (2011). Does Input Quality Drive Measured Differences in Firm Productivity? National Bureau of Economic Research Working Paper No. 16853.

Griffith, R., and H. Harmgart. (2005). "Retail Productivity". International Review of Retail, Distribution and Consumer Research, 15 (3): 281-90. 
Griffith, Rachel, Rupert Harrison, Jonathan Haskel, and Mari Sako. (2003). The UK Productivity Gap and the Importance of the Service Sectors. Advance Institute of Management (AIM) Briefing Note, http://www.aimresearch.org/uploads/pdf/ Academic\%20Publications/rgbrief.pdf (accessed September 15, 2014)

Gronroos, C., and K. Ojasalo. (2004). "Service Productivity: Towards a Conceptualization of the Transformation of Inputs into Economic Results in Services." Journal of Business Research, 57: 414-23.

Gustavsson, S. O. (1984). 'Flexibility and Productivity in Complex Production Processes." International Journal of Production Research, 22 (5): 801 -8.

Hausman, J. A. (1978). “Specification Tests in Econometrics.” Econometrica, 46 (6):1251-71. Hempell, T., and T. Zwick. (2005). Technology Use, Organizational Flexibility and Innovation: Evidence for Germany. ZEW Discussion Paper No. 05-57, Mannheim.

Higon, A. D., O. Bozkurt, J. Clegg, I. Grulis, S. Salis, N. Vasilakos, and A. M. Williams. (2010). "The Determinants of Retail Productivity: A Critical Review of the Evidence." International Journal of Management Reviews, 12 (2): 201-17.

Hu, B. A., and L. A. Cai. (2004). "Hotel Labour Productivity Assessment." Journal of Travel and Tourism Marketing, 16 (2-3): 27-38.

Janta, H., A. Ladkin, L. Brown, and P. Lugosi. (2011). "Employment Experiences of Polish Migrant Workers in the UK Hospitality Sector.” Tourism Management, 32 (5): 100619.

Johns, N., B. Howcroft, and L. Drake. (1997). "The Use of Data Envelopment Analysis to Monitor Hotel Productivity." Progress in Tourism and Hospitality Research, 3 (2): 119 -27 .

Jones, P., and A. Lockwood. (2002). The Management of Hotel Operations, London: Cengage. 
Jones, P., and A. Siag. (2009). “A Re-Examination of the Factors that Influence Productivity in Hotels: A Study of the Housekeeping Function.” Tourism and Hospitality Research, 9 (3): 224-34.

Kangasniemi, M., M. Mas, C. Robinson, and L. Serran. (2009). The Economic Impact of Migration: Productivity Analysis for Spain and the UK. MPRA Paper 15835, http://mpra.ub.uni-muenchen.de/15835/ (accessed September 15, 2014).

Kappa, M. M., A. Nitschke., and P. B. Schappert. (1997). Managing Housekeeping Operations. 2nd edition, The Educational Institute of the American Hotel and Motel Association: East Lansing, MI.

Kelliher C. (1989). "Flexibility in Employment: Developments in the Hospitality Industry." International Journal of Hospitality Management, 8(2): 157-66.

Ketkar, S. and Sett, P. K. (2005). ”HR Flexibility and Firm Performance: Analysis of a MultiLevel Causal Model”. International Journal of Human Resource Management 20(5): 1009-38.

Kleinknecht, A, R. M. Oostendorp, M. P. Pradhan, and C. W. N. Naastepad. (2006). "Flexibile Labour, Firm Performance and Dutch Job Creation Miracle." International Review of Applied Economics, 20 (2): 171-87.

Koch, M. J., and R. G. McGrath. (1996). “Improving Labour Productivity: Human Resources Management Policies Matter.”Strategic Management Journal, 17 (5): 335-54.

Li P., and D. Prescott. (2010). "Labour Productivity in the Canadian Tourism Sector." Canadian Tourism Human Resource Council. http://cthrc.ca/ /media/Files/CTHRC/ Home/research_publications/productivity/Labour_Productivity_Canadian_TourismCu rrentEN.ashx (accessed September 25, 2014). 
Lockwood, A., and Y. Guerrier. (1989). "Flexible Working in the Hospitality Industry: Current Strategies and Future Potential.” International Journal of Contemporary Hospitality Management, 1 (1): 11-6.

Lucas, R., and S. Mansfield. (2010). "The Use of Migrant Labour in the Hospitality Sector: Current and Future Implications." In: Ruhs M and Anderson B (eds) Who Needs Migrant Workers? Labour Shortages, Immigration and Public Policy. Oxford: Oxford University Press, pp. 159-86.

Lucidi, F., \& Kleinknech, A. (2010). Little innovation, many jobs: An econometric analysis of the Italian labour productivity crisis. Cambridge Journal of Economics, 34, 525-546

Markova, E., A. Paraskevopoulou, A. M. Williams, and G. Shaw. (2013). "Migrant Workers in Small London Hotels: Employment, Recruitment and Distribution'. European Urban and Regional Studies, DOI: 10.1177/0969776413513913.

Mason, G., C. Robinson., and C. S. Bondibene. (2009). Sources of Labour Productivity Growth at Sector Level in Britain 1998-2007: A Firm Level Analysis. London: NESTA, NESTA Working Paper 14/09

McMahon, F. (1994). "Productivity in the Hotel Industry." In A. V. Seaton (Ed.), Tourism: The State of the Art. Chichester, England: Wiley, pp. 616-25.

Michie, J., and M. Sheehan. (2001). "Labour Market Flexibility, Human Resource Management and Corporate Performance.” British Journal of Management, 12 (4): 287-306.

Michie, J., and M. Sheehan. (2005). "Business Strategy, Human Resources, Labour Market Flexibility and Competitive Advantage." International Journal of Human Resource Management, 16 (3): 445-64.

Mill, R. C. (2008). “Managing Labour Productivity.” In: P. Jones (ed.) Handbook of Hospitality Operations and IT. Oxford, UK: Butterworth Heinemann, pp. 269 - 94. 
Miller, D. and J. Shamsie. (1996). "The Resource-Based View of the Firm in Two Environments: The Hollywood Film Studios from 1936 to 1965." Academy of Management Journal, 39: 519-43.

Nickson, D. (2010). Human Resource Management for the Hospitality and Tourism Industries. Burlington, MA: Elsevier.

OECD (2001). Measuring Productivity: Measurement of Aggregate and Industry-Level Productivity Growth. Paris: OECD 2001.

Piore, M. J. (1979). Birds of Passage: Migrant Labour and Industrial Societies. New York: Cambridge University Press.

Reardon, J., and I. Vida. (1998). "Measuring Retail Productivity: Monetary vs. Physical Input Measures." International Review of Retail, Distribution and Consumer Research, 8: $399-413$.

Reynolds, J., E. Howard, D. Dragun, B. Rosewell, and P. Ormerod. (2005). “Assessing the Productivity of the Retail Sector." International Review of Retail, Distribution and Consumer Research, 15: 237-80.

Roca-Puig, V., Beltrán-Martín, I., Bou-Llusar, J. C., and Escrig-Tena, A. B. (2008) "External and Internal Labour Flexibility in Spain: a Substitute or Complementary Effect on Firm Performance?” The International Journal of Human Resource Management, 19: 113151

Rust, R. T., and M-H. Huang. (2012). “Optimizing Service Productivity.” Journal of Marketing, 76: 47-66.

Saint-Paul, G. (1996). Employment Protection, International Specialization, and Innovation. International Monetary, Research Department, Working Paper No. 96/16.

Scott, S. (2013). "Labour, Migration and the Spatial Fix: Evidence from the UK Food Industry." Antipode, 45 (5): 1090-109. 
Sethi, A. K., and S. P. Sethi. (1990). "Flexibility in Manufacturing: A Survey." International Journal of Flexible Manufacturing Systems, 2: 289 -328.

Siebers, P.-O., U. Aickelin, G. Battisti, H. Celia, C. Clegg, X. Fu, R. De Hoyos, and A. Iona. (2007). Enhancing Productivity: the Role of Management Practices. London: Advanced Institute of Management, Working paper No. 65.

Sigala, M., P. Jones, A. Lockwood, and D. Airey. (2005). "Productivity in Hotels: A Stepwise Data Envelopment Analysis of Hotels' Rooms Division Processes." The Service Industries Journal, 25 (1): 61-81.

Sisson, K., and P. Marginson. (2003). "Management Systems, Structure and Strategy." in P. Edwards (ed.) Industrial Relations: Theory and Practice, 2nd edition, Oxford: Blackwell.

Soltani, E., and A. Wilkinson. (2010). "What is Happening to Flexible Workers in the Supply Chain Partnerships between Hotel Housekeeping Departments and Their Partner Employment Agencies?” International Journal of Hospitality Management, 29: 10819.

Son, Y. K., and C. S. Park. (1987). "Economic Measures of Productivity, Quality and Flexibility in Advanced Manufacturing Systems." Journal of Manufacturing Systems, $6(3): 193-207$.

Syverson, C. (2011). “What Determines Productivity?' Journal of Economic Literature, 49 (2): $326-65$.

Thompson, G. M. (1998). “Labor Scheduling, Part 2: Knowing How Many on Duty Employees to Schedule." Cornell Hotel and Restaurant Administration Quarterly, 39 (6): 26-37.

Tilly, C., and C. Tilly. (1997). Work Under Capitalism. Boulder, CO: Westview Press.

Waldinger, R., and Lichter, M. I. (2003). How the Other Half Work: Immigration and the Social Organisation of Labour. University of California Press: Berkeley. 
Wall, T. D., and S. J. Wood. (2005). "Romance of Human Resource Management and Business Performance, and the Case for Big Science.” Human Relations, 58: 429-62.

Warhurst, C., and D. Nickson. (2007). "Employee Experience of Aesthetic Labour in Retail and Hospitality." Work, Employment and Society, 21 (1): 103-20.

White, M., S. Hill, C. Mills, and D. Smeaton. (2004). Managing to Change? British Workplaces and the Future of Work, Palgrave Macmillan.

Williams, A. M. (2009). “Employability and International Migration: Theoretical Perspectives.” in S MacKay (ed.), Refugees, Recent Migrants and Employment, challenging barriers and exploring pathways, Oxford: Routledge, pp 23-34.

Witt, C. A., and S. F. Witt. (1989). "Why Productivity in the Hotel Sector is Low." International Journal of Contemporary Hospitality Management, 1 (2): 28-34.

Wooldridge, J. (2008). Introductory Econometrics: A Modern Approach. Thomson SouthWestern.

Wong, K. K. F. (2004). "Industry-Specific and General Environmental Factors Impacting on Hotel Employment." Asia Pacific Journal of Tourism Research, 9 (1): 19-28. 


\section{Notes}

i Both right and left hand side variables are logged in equation (i) (excluding binary variables) to obtain a constant elasticity interpretation of the effect of the independent on the dependent variables.

ii This implies there are nine time binary variables covering the years 2005-2013. The year binary variables are employed for the time fixed effects instead of the month dummies to avoid a proliferation of time binary variables in the estimations; employing the month dummies amounts to the use of 108 binary variables. Also, the binary variable for the first year, 2005, is dropped to avoid the dummy variable trap.

iii The hotels do not keep records of nationalities and genders of outsourced workers-agency employees. They only keep data on actual working hours, hourly rates paid to agency workers and (employment) agencies supplying the workers. Thus, data used for computing the shares of migrant(UK), zero (permanent) contract and female (male) hours are obtained from records of employees directly employed by the hotels' human resources departments.

iv The substituted variables - migrant and UK hours, zero and permanent contract hours, and, male and female hours - cannot be entered simultaneously into the right-hand side of the base model due to collinearity. It is worth noting that the substitution of these three variables into the benchmark model generally leads to very marginal changes in the estimated coefficients and significance of other variables in the model. Statistical inference on the coefficients of other variables from this variable substitution largely remains unchanged.

$v \quad$ Similarly, the crisis variable is negatively associated with physical but not financial productivity in food and beverage department. 